\title{
Detection System Design for Cu Contaminated Water Based on Red Diode Laser and LDR (Light Dependent Resistor) Sensor
}

\author{
Frida Agung Rakhmadi*, Hikmahtuz Zahroh** \\ Department of Physics, Faculty of Science and Technology, UIN Sunan Kalijaga Yogyakarta \\ Jl. Marsda Adisucipto No 1 Yogyakarta 55281, Indonesia. Tel. +62-274-540971, Fax. +62-274-519739. \\ Email: agungfrida@yahoo.co.id*, hikmah.zahroh@gmail.com**
}

\begin{abstract}
Rakhmadi F A, Zahroh H. 2017. Detection System Design for Cu Contaminated Water Based on Red Diode Laser and LDR (Light Dependent Resistor) Sensor. Proc Internat Conf Sci Engin 1: 99-101. The research on making detection system of Cu contaminated water based on red diode laser and LDR sensor has been done. The purpose of this research was to know the characteristic of LDR sensor, to make the detection system of $\mathrm{Cu}$ contaminated water, and to test the detection system of $\mathrm{Cu}$ contaminated water. This research was conducted in five phases: characterization of LDR sensor, making data acquisition system, processing and analyzing of train sample data, making detection system, and implementation of detection system on test sample. The result of LDR sensor characterization in this research showed transfer function $\mathrm{V}=0,004 \mathrm{I}+2,1861$ with relation of input-output relation which was very strong $(\mathrm{r}=0,99267)$; sensitivity was 0,004 volt/lux; repeatability was $99,015 \%$, and saturation for the light intensity $>500$ lux. Meanwhile, the succes rate of detection implementation on $\mathrm{Cu}$ contaminated water was $97,5 \%$.
\end{abstract}

Keywords: Detection, LDR, red diode laser

\section{INTRODUCTION}

Water is a major component of life. Water becomes essential need for drinking, cooking, bathing, and so on. Therefore, the quality of water should always be maintained from pollutant substances. Consuming contaminated water can cause some diseases such as disruption of the digestive system (Anonymous. 1994). Other consequences of water pollution are the decrease of efficiency, yield, productivity, carrying capacity and the capacity of water resources which in turn will decrease the natural resources depletion (Mustikasari. 2013).

One of water pollutants is copper $(\mathrm{Cu})$. The maximum concentration of $\mathrm{Cu}$ allowed in water is 2 ppm (Kusnaedi, 2010). If the level of $\mathrm{Cu}$ in water exceeds the threshold, the water can be clasified as $\mathrm{Cu}$ contaminated water.

Efforts to maintain clean water from $\mathrm{Cu}$ should be done. One effort that can be done is monitoring of $\mathrm{Cu}$ contaminated water. This research focused on the detection of water contaminated by $\mathrm{Cu}$.

The tool most commonly used tool to detect the presence of $\mathrm{Cu}$ in water is Atomic Absorption Spectroscopy (AAS). This detection tool has advantages in terms of ease of operation, speed of data readings, and its sensitivity to changes in the concentration of detected samples (Supriyanto and Kamal, 2012). However, not all laboratories have it because of its relatively expensive price and high cost of care (Kristianingrum, 2007).

To overcome the weaknesses of AAS many researchs have been done by researchers. The result was alternative methods besides AAS have been found, namely electromagnetic induction (Rakhmadi et.al, 2015) and fluorescence (Jung et.al, 2016).

This research aimed to the reference of detection device of $\mathrm{Cu}$ contaminated water. In this research, a detection device of $\mathrm{Cu}$ contaminated water was made by using red diode laser and LDR sensor. The use of red diode laser and LDR sensor because of low power consumption and low price.

\section{MATERIALS AND METHODS}

\section{Characterization of LDR sensor}

Characterization of LDR sensor includes transfer function and their input output relationship, sensitivity, repeatability, and saturation.

\section{Manufacturing of detection system}

Manufacturing of detection system based on Figure 1 and 2.

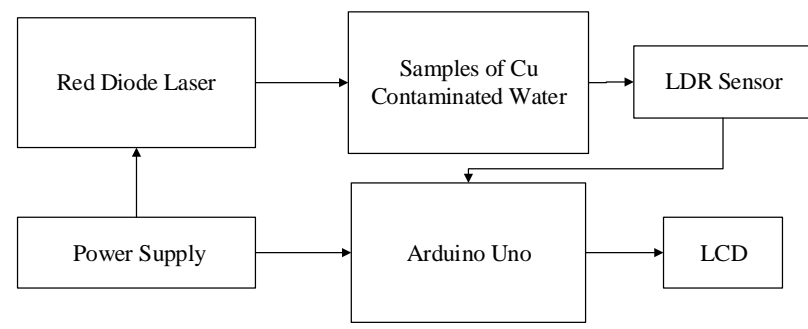

Figure 1. Block diagram of detection system hardware. 


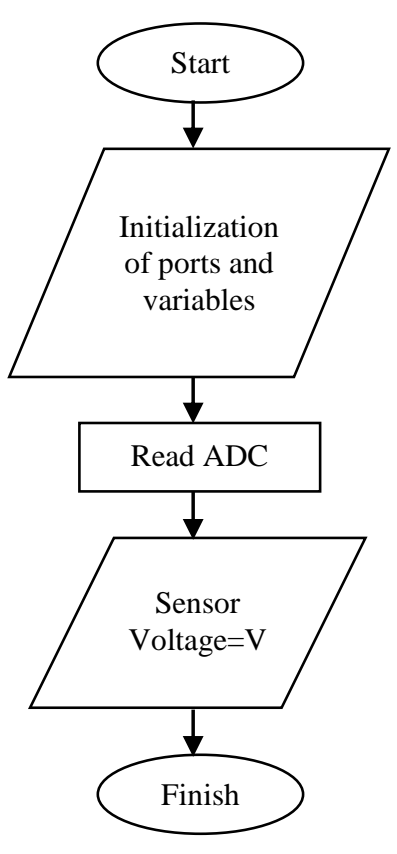

Figure 2. Flow chart of detection system software.

After data acquisition system has been completed, the next step was preparing of training samples, retrieving of data from the training samples, processing of training samples data, and entering of training samples data into data acquisition system. The training samples were $\mathrm{Cu}$ contaminated water with concentration of $1 \mathrm{ppm}(\mathrm{mg} / \mathrm{L}), 2 \mathrm{ppm}(\mathrm{mg} / \mathrm{L}), 3 \mathrm{ppm}(\mathrm{mg} / \mathrm{L})$, and $4 \mathrm{ppm}(\mathrm{mg} / \mathrm{L})$. The retrieval of data from training samples was done by noting the output voltage of data acquisition system for each sample. The data were then searched for boundary values for $\mathrm{Cu}$-contaminated water that was still permitted with those that was not permitted. The boundary value was inserted into software in arduino uno.

\section{Implementation of Detection System}

Before detection system implemented in the test samples, firstly prepared a set of test samples in the form of $\mathrm{Cu}$ contaminated water with concentration of $1 \mathrm{ppm}$ (mg / L), $2 \mathrm{ppm}(\mathrm{mg} / \mathrm{L}), 3 \mathrm{ppm}(\mathrm{mg} / \mathrm{L})$ and $4 \mathrm{ppm}$ (mg / L ). When the detection system tested on $\mathrm{Cu}$ contaminated water with concentration of $1 \mathrm{ppm}(\mathrm{mg} /$ L) and $2 \mathrm{ppm}(\mathrm{mg} / \mathrm{L})$, it should be stamped "STANDARD" on the LCD layer. If the detection system displays "STANDARD" on the LCD layer, it is marked " $\sqrt{ }$ in the standard column. However, if the system displays "CONTAMINATED CU .. !!" on the LCD screen, it is marked " $\sqrt{ }$ " in the $\mathrm{Cu}$ contaminated column. Furthermore, the test results are calculated percentage of success with the following formula.

Percentage of succesfull $=($ number of correct $/ 10) \times 100 \%$.

\section{RESULTS AND DISCUSSION}

\section{Characterization of LDR sensor}

The result of characterization of LDR sensor in this research showed transfer function of LDR sensor was $\mathrm{V}$ $=0,004 \mathrm{I}+2.1861$ and its input-output relationship was very strong with correlation coefficient $\mathrm{r}=0.99267$; sensor sensitivity wasf 0.004 volts / lux; sensor repeatability was $99.015 \%$; and sensor saturation was at light intensity $>500$ lux.

\section{Manufacturing of detection system}

Detection system of $\mathrm{Cu}$-contaminated water based on red laser diode and LDR sensor that has been made was shown in Figure 3.

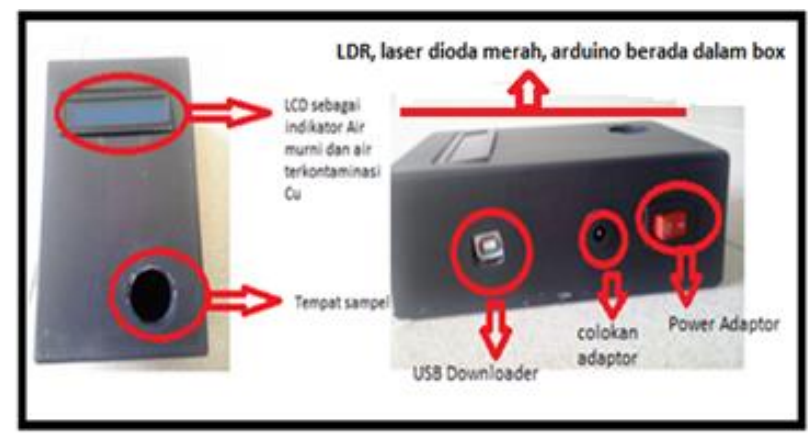

Figure 3. Detection system of Cu-contaminated water.

When power supply was on, microcontroller will instruct LDR sensor to read the intensity of light that not absorbed by sample. Next, the output of sensor were transmitted to microcontroller to be converted into digital signal. The digital signal was further processed using transfer function of LDR sensor, so the output can be displayed on LCD screen with volt unit.

Implementation result of data acquisition system on samples of $\mathrm{Cu}$-contaminated water with concentration of $1 \mathrm{ppm}, 2 \mathrm{ppm}, 3 \mathrm{ppm}$ and $4 \mathrm{ppm}$ respectively obtained the average voltage of sensor output were 3,232 volt, 3,114 volt, 3,054 volt and 2,984 volt. This result showed that greater of $\mathrm{Cu}$ concentration in water made smaller of voltage sensor output.

Decreasing of sensor output voltage along with increasing of $\mathrm{Cu}$ concentration because of more light of red diode laser was absorbed by sample or less light of red diode laser was passed. The less of red diode laser light was transmitted, the lower of LDR sensor output voltage.

The sensor output voltage of $3.11 \mathrm{~V}$ which the smallest voltage value in sample of $\mathrm{Cu} 2 \mathrm{ppm}$ was a boundary value. If the sensor output voltage exceeds boundary value, then water was still feasible. However, when the sensor output voltage was below of boundary value then the water was not feasible.

The detection system has an output indicator on LCD. If the water was still feasible, then the LCD will display script "Standard", but when the water was not 
feasible then the LCD will display script "CuContaminated".

\section{Implementation of Detection System}

Implementation of detection system on test samples was shown in Table 1.

Table 1. Implementation of detection systems on test samples.

\begin{tabular}{ccc}
\hline $\begin{array}{c}\text { Cu-contaminated } \\
\text { water (ppm) }\end{array}$ & $\begin{array}{c}\text { Success } \\
\text { Percentage }\end{array}$ & $\begin{array}{c}\text { Rate of success } \\
\text { percentage }\end{array}$ \\
\hline 1 & $100 \%$ & \\
2 & $90 \%$ & $97,5 \%$ \\
3 & $100 \%$ & \\
4 & $100 \%$ & \\
\hline
\end{tabular}

According to table 1, implementation of detection system in test samples has a success rate of $97.5 \%$. The success has met international standards of $97 \%$ (Suryono, 2012).

Although its success has exceeded international minimum standard, the success of detection system has not reached $100 \%$. This, allegedly because there were environmental lights that detected by LDR sensor.

\section{CONCLUSIONS}

The result of LDR sensor characterization in this research showed transfer function $\mathrm{V}=0,004 \mathrm{I}+2,1861$ with relation of input-output relation which was very strong $(\mathrm{r}=0,99267)$; sensitivity was 0,004 volt/lux; repeatability was $99,015 \%$, and saturation for the light intensity $>500$ lux. Meanwhile, the succes rate of detection implementation on $\mathrm{Cu}$ contaminated water was $97,5 \%$.

\section{REFERENCES}

Anonymous. 1994. Indonesian Environment and Development. The World Bank, Washington.

Mustikasari. 2013. Kelembagaan Air Indonesia. Telapak \& Both End, Bogor.

Kusnaedi, 2010. Mengolah Air Kotor Untuk Air Minum. Penebar Swadaya, Jakarta.

Supriyanto C.S., Kamal, Z. 2012. Analisis Cemaran Logam Berat $\mathrm{Pb}, \mathrm{Cu}$ dan $\mathrm{Cd}$ pada Ikan Air Tawar dengan Metode Spektrometri Nyala Serapan Atom (SSA). Prosiding Seminar Nasional III SDM Teknologi Nuklir.

Kristianingrum, S. 2007 Modifikasi Metode Analisis Spesiasi Merkuri dalam Lingkungan Perairan. Prosiding Seminar Nasional Penelitian, Pendidikan dan Penerapan MIPA.

Rakhmadi FA, Dewi AR, Azizi, AF. 2015. Design of Detection Device for $\mathrm{Cu}$ Contaminated Water Using Induction Principle. Indonesian Journal of Applied Physics. 5(1):79-85.

Jung KH, Oh ET, Park HJ, Lee KY. 2016. Development of New Peptide-based Receptor of Fluorescent Probe with Femtomolar Affinity for $\mathrm{Cu}^{+}$and Detection of $\mathrm{Cu}^{+}$in Golgi Apparatus. Biosensors and Bioelectronics 85:437-444.

Suryono. Worksop Peningkatan Mutu Penelitian Dosen dan Mahasiswa. Yogyakarta: Program Studi Fisika UIN Sunan Kalijaga.2012. 
THIS PAGE INTENTIONALLY LEFT BLANK 